\title{
Correction to: Imaging plant responses to water deficit using electrical resistivity tomography
}

\author{
Sathyanarayan Rao (D) Nolwenn Lesparre • Adrián \\ Flores-Orozco • Florian Wagner • Andreas Kemna • \\ Mathieu Javaux
}

Published online: 5 November 2020

(C) The Author(s) 2020

\section{Correction to: Plant Soil (2020) 454:261-281 https://doi.org/10.1007/s11104-020-04653-7}

The article "Imaging plant responses to water deficit using electrical resistivity tomography", written by Sathyanarayan Rao, Nolwenn Lesparre, Adrián Flores-

The online version of the original article can be found at https://doi.org/10.1007/s11104-020-04653-7

\section{S. Rao $(\bowtie) \cdot$ M. Javaux}

Department of Environmental Sciences, Earth and Life Institute, Université Catholique de Louvain, Louvain-la-Neuve, Belgium e-mail: Sathyanarayan.rao@uclouvain.be

\section{N. Lesparre}

Laboratoire d'Hydrologie et Géochimie de Strasbourg, University of Strasbourg/EOST/ENGEES, CNRS UMR7517, 1 Rue Blessig, 67084 Strasbourg, France

\section{A. Flores-Orozco}

Geophysics Research Group, Vienna University of Technology, Gusshausstraße 27-29, E120-3, 1040 Vienna, Austria

\section{F. Wagner}

Institute for Applied Geophysics and Geothermal Energy, RWTH Aachen University, Aachen, Germany

\footnotetext{
A. Kemna

Geophysics Section, Institute of Geosciences, University of Bonn, Bonn, Germany

M. Javaux

Agrosphere, IBG3, Forschungszentrum Jülich GmbH, Jülich, Germany
}

Orozco, Florian Wagner, Andreas Kemna and Mathieu Javaux, was originally published Online First without Open Access. After publication in volume 454, issues 1-2, pages 261-281 the author decided to opt for Open Choice and to make the article an Open Access publication. Therefore, the copyright of the article has been changed to (C) The Author(s) 2020 and the article is forthwith distributed under the terms of the Creative Commons Attribution 4.0 International License, which permits use, sharing, adaptation, distribution and reproduction in any medium or format, as long as you give appropriate credit to the original author(s) and the source, provide a link to the Creative Commons licence, and indicate if changes were made. The images or other third party material in this article are included in the article's Creative Commons licence, unless indicated otherwise in a credit line to the material. If material is not included in the article's Creative Commons licence and your intended use is not permitted by statutory regulation or exceeds the permitted use, you will need to obtain permission directly from the copyright holder. To view a copy of this licence, visit http://creativecommons.org/licenses/by/4.0.

The original article has been corrected.

Open Access This article is licensed under a Creative Commons Attribution 4.0 International License, which permits use, sharing, adaptation, distribution and reproduction in any medium or format, as long as you give appropriate credit to the original author(s) and 
the source, provide a link to the Creative Commons licence, and indicate if changes were made. The images or other third party material in this article are included in the article's Creative Commons licence, unless indicated otherwise in a credit line to the material. If material is not included in the article's Creative Commons licence and your intended use is not permitted by statutory regulation or exceeds the permitted use, you will need to obtain permission directly from the copyright holder. To view a copy of this licence, visit http://creativecommons.org/licenses/by/4.0/.

Publisher's note Springer Nature remains neutral with regard to jurisdictional claims in published maps and institutional affiliations. 